Errata

\title{
Sequence of psi, a gene on the symbiotic plasmid of Rhizobium phaseoli which inhibits exopolysaccharide synthesis and nodulation and demonstration that its transcription is inhibited by psr, another gene on the symbiotic plasmid
}

D. Borthakur and A.W.B. Johnston

John Innes Institues, Colney Lane, Norwick NR4 7UH, UK

Mol Gen Genet (1987) 207:149-154

The final sentence of the Summary should read:

Using gene fusions between $p s i$ and $l a c Z$, it was found that $p s r$ inhibited transcription of $p s i^{\prime \prime}$.

\section{A mutant of Chlamydomonas reinhardtii altered in the transport of ammonium and methylammonium}

\author{
A.R. Franco, G. Cárdenas, and E. Fernández \\ Departamento de Bioquimica, Facultad de Ciencias, Universidad de Córdoba, E-14071 Córdoba, Spain \\ Mol Gen Genet (1987) 206:414-418 \\ The following reference should be added: \\ Cullimore JV, Sims AP (1981) Pathway of ammonia assimilation in illuminated and darkened Chlamydomonas reinhardii. Phytochemistry \\ $20: 933-940$
}

